\title{
Faith, hope and love in sport
}

\author{
Jernej Pisk
}

\author{
St. Stanislav's Institution, Ljubljana, Slovenia \\ jernej.pisk@gmail.com
}

\begin{abstract}
In the Christian religious tradition, theological virtues of faith, hope and love have a central role. Along with the cardinal virtues of prudence, justice, fortitude and temperance they present the whole of the good human life. While cardinal virtues can be cultivated by human will, faith, hope and love are given by God and therefore open 'natural' human life on Earth toward transcendent spiritual realities. Human beings as bio-psycho-social and spiritual beings incorporate theological virtues in all the activities of their life. In sport, faith, hope and love have an important, though often neglected, role. On a practical level faith can be recognized in any relation between athlete and coach. To trust one's coach, without any guarantee that the outcome of prescribed workouts will lead to the desired results, needs strong faith, trust and confidence. Moreover, faith is the virtue that makes sport so attractive also for spectators even to the point of being a'secular' religion for the masses. Hope is the virtue of'not yet' or of something 'being on its way'. For most athletes, daily workouts are not a goal, but just the means to that end. Any reason for doing sports needs a hope behind it in order to move or will oneself to action. Along with hope, understood as a golden mean, we find despair on the one hand and 'false hope' on the other. Both are corruptions of hope seen daily in the world of sport. To manage hope in sport practices correctly offers a path to success in sport at all levels. Love is at the apex of the theological virtues. There are many formulations of love both in ancient Greek and Roman times: eros, agape, caritas, amor. Each has its special characteristic meaning also in sport. In sport we can see laughter and tears because any love is connected with highest human joy and deepest depression. Yet, in summation, it is argued that love in sport must be understood as the binding force and source of cooperation and fulfilled life for any athlete qua human being.
\end{abstract}

\section{KEYWORDS}

sport; theological virtues; ethics; faith; hope; love; spirituality

DOI

https://doi.org/ 10.14712/23366052.2017.12

(c) 2017 The Author. This is an open-access article distributed under the terms of the Creative Commons Attribution License (http://creativecommons.org/licenses/by/4.0), which permits unrestricted use, distribution, and reproduction in any medium, provided the original author and source are credited. 


\section{INTRODUCTION}

Sport has long been connected with religious dimensions of human beings. This connection may be more explicit, as in Homer's writings and in the ancient Olympics, or more implicit, as in a modern secular religion of sport from Coubertin's ideas on to modern times (Parry, 2007). But why are sport and religion so closely connected? One common element or connection between sport and religion is the human being, qua believer and athlete; so the answer that will be offered below will focus on some characteristics of being human, and the human capacity for spiritual life. The focus will be on three classical theological virtues: faith, hope and love, which are in Christian teaching understood as a 'pledge of the presence and action of the Holy Spirit in the faculties of the human being' as presented in the Compendium (2005, p. 384).

So, no matter what man is doing, in deeds of faith, hope and love the spiritual dimensions of human being are manifested. Faith, hope and love were recognized from ancient times onwards as a means to help people grow spiritually (Augustine, 1955). In present times, too, cultivating those virtues can be a way to God and personal spiritual development (Ratta, 2014). The whole life of any spiritual human being should be touched (and, ideally, filled) with these three virtues. It is not surprising, therefore, that faith, hope and love play an important role in every activity, and also in sport. Moreover, it is not only religious people who experience faith, hope and love in sport; non-believers do, too. This leads us to two insights: that human beings as such are spiritual beings, and that sport as human activity is in itself open to spirituality. As already mentioned this fact is not something new, since from ancient times athletic events were connected with religious rituals (Sansone, 1993). Nevertheless, our task here is more explicitly to reveal this connection, recognizing theological virtues of faith, hope and love as something common in everyday sporting practices.

\section{Spiritual dimensions of sport through theological virtues of faith, hope and love}

We can say that religions are external manifestations of the similar inner spiritual experiences of people. We start, then, with a consideration of the religious dimensions of sport. First, it is possible to recognize that sport and religion are once again becoming more closely aligned. On the one hand, some religious practices, like walking or biking pilgrimages, have become truly sporting tests and/or events. On the other hand, sport has become a place of deep faith, source of hope and experience of love for many people. Today, sport may be seen as the last transformation of traditional confessional religions and the only religion for many people. Sport is increasingly becoming a religion and religion is becoming a sport. The borders between the two, at first sight opposing human practices, one focusing on the body and the other on the soul, are diminishing. As we have already seen, this is not something new and not even surprising, because as we will see both practices highly estimate faith, hope and love. But before we focus on these three theological virtues, let consider some other reasons for religiosity of sport.

It is hard to avoid the well-known saying of Karl Marx that "religion is [...] the opium of the people" (2009, p. 3). Religion is, for Marx, an anaesthetic for the exploited masses. Indeed, religion proved to be a very successful medicine in healing pain: 
religion indeed gives the meaning to pain. Although Friedrich Nietzsche directed his criticism of religion to this fact, religion proved to be a good medicine against pain. However, in some modern societies where confessional religions are not present or strong any more, many people find their anti-pain 'opium' in sport. If we paraphrase Marx's saying we get: "Sport is the opium of the people." Once again, this is not something surprising because it was obviously well known by many more or less totalitarian state leaders, e.g. in 20th century Eastern Europe.

Similarly Michael Novak (1988, p. 183) characterizes the faith of people from USA with the saying: "In sport we (should not) trust." Furthermore, Thomas Luckmann (1967, p. 72) recognized the 'invisible' religion in any meaning-system for a society or an individual. Thus, the invisible religion of modern man can be, among others, sport (Pisk, 2010). The religious believers and believers in sport share many things: they search for salvation in special 'sacred' space and time, and adore their G(g)od(s). There are regular rituals, symbols, poems, strong group cohesion and relics. In both cases the option of achieving immortality is offered (Pisk, 2012). Here and there miracles happen, and after the fall it is possible to 'forgive sins' and start again from the beginning.

From the other side, some religious practices are more like sport. For an average modern western believer sport is an important means of searching for the self and for meaning in life. It may represent a kind of 'spiritual wellness' or 'soul-wellness', much like sport practices are important for 'body wellness'. The shared aim is in attaining an inner harmony (Jirásek, 2015, p. 297). This can be attained by different body-spiritual practices, like meditation, yoga, etc. The meaning of anthropocentric exercises like these is similar to the meaning of body exercises - the (self-centred) search for the self, peace and meaning. Also salvation is not understood as a gift, or the gift of grace of any deity anymore, but must be earned by one's own work. Therefore, the temptation of self-salvation is very frequent in sport as well as in this kind of religion. In this manner in religious and spiritual personal life, practices from sport - such as meritocracy may be introduced.

The interconnections of sport and religion within the search for meaning and self-salvation, while important, do not reveal the whole picture. Modern pilgrimages can be understood as sport-like tests of personal endurance, the search for the self and one's other capabilities. Yet sport can also be the place for developing and ramifying meaning and thus the essence of one's own life. Yet, the question of deeper congeniality between sport and religion, between the sporting life and the spiritual life of the human being, is still unanswered simply by observing these commonalities. Therefore, our further investigation must try to expose deeper similarities between the two, focusing on three classical theological virtues: faith, hope and love. We will show how these three virtues shape human experiences in sport. Faith, hope and love are more than just something arbitrary in sport. They can partly reveal to us the essence of sport - they make sport attractive, something special and worth engaging in. Through faith, hope and love, it will be argued, the spiritual dimensions of sport are revealed. 


\section{Faith in Sport}

Immanuel Kant defines faith or belief ${ }^{1}$ as a subjectively adequate but objectively inadequate acceptance of something as true $(1896, \mathrm{p} .741 \mathrm{f})$. A believer is someone who possesses no exact knowledge of the thing(s) (s)he believes. In religious discourse, there is a sense in which it is redundant to speak of 'belief' where the subject of that belief could be proven. Josef Pieper, who wrote about faith, hope and love, emphasized that there are two important elements of any faith: "Unfamiliarity with the subject matter and yet, at the same time, unconditional conviction of its truth" (Pieper, 2012, p. 23). But, as Pieper further emphasized, the believer must know enough about the matter to understand "what it is all about", in order to open up a path to recognizing the role of faith in sport.

Faith is definitely no stranger in sport. Among other things every competition confronts athletes with unknown future outcomes. If somebody could know (not merely believe) that they would accomplish the task perfectly or win the competition, then why try? The meaning of the contest would disappear. The results of contests test our beliefs and show if they were well-founded or not. Athletes are not entirely ignorant concerning their beliefs. They must know enough to understand what is going on: athletes believe that they can accomplish the task, though they cannot guarantee it before the fact. A good skiing coach will not let their charges attempt a run before they are ready for it, irrespective of the confidence of the novice. Yet athletes must believe that they can make progress with training, that they are capable of accomplishing different and superior tasks, to make it to the finish line, and so on.

Athletes believes that their trainer or coach is the one who can help them on their way. If they stop believing - and lose confidence - in their trainer, then it is time to change them. A part of one's predispositions as a successful athlete is a prior belief in oneself that cannot be atomised; athletic success is no orphan. Athletic self-belief is wrapped up with the belief of critical others such as the coach or trainer. Without strong belief in his trainer and his programme of workouts it is difficult, perhaps impossible, to succeed (Vodeb, 2001, p. 203).

So it is very important for the trainer or coach to be as trustworthy a person as possible, because this is in part the foundation of the faith of the athlete's belief in themselves too. Besides his own knowledge of sport, a good trainer must work on his own credibility and develop it. Yet the abilities of the trainer are not enough. Every athlete must understand what the trainer wants or demands of them, and judge reasonably the extent to which their instructions make sense. ${ }^{2}$ Aquinas states (1920, II, II, 8, 8 ad 2): "Man could not believingly assent to any proposition if he did not in some way understand it." Trainers convince athletes to trust in them, in their experience, replacing doubt with reference to past results and with the strength of their knowledge and character.

1 'Faith' or 'belief'? We will use these two words interchangeably. The Latin word 'fides' can be translated both ways.

2 Success, here, may of course be understood in relation to external goods such as adulation and trophies but may just as well be understood in terms of accomplishments related to the internal goods of the activity (Brown, 1992; McNamee, 1995). 
From these everyday interactions, it is clear that two things are in play: to believe always means to believe someone and to believe something (Aquinas, 1920, II, II, 129, 6); and to believe someone seems to be the more important of the two. That is clear in sport training as well: the athlete must first believe a given person (coach, co-player, event organizer, captain, masseur, scientist and so on), and only after that does he believe a given matter (training programme, etc.). The reason why we believe something is because we believe someone. This faith of the athlete in others runs deep. This is important, since if the athlete is to pledge all his powers, time, money and even his own life in sport, they must be assured of the possibility of success therein. Athletes do not have rock solid assurance that their investment in sport will pay off. So faith plays a central role in every athlete's life. Confidence in the competence of critical others is paramount. Mature athletes will judge trainers using their own experience but nevertheless the athlete's faith is not grounded on scientific proofs, because it cannot be: it is rather reasonable faith about his or her unpredictable future.

John Caputo has made a useful distinction here between 'relative' and 'absolute' future, which can help us understand what is going on in sport, and why sport is so attractive.

There is a relatively foreseeable future, the future for which we are planning, the future on which we are all hard at work, the future we are trying to provide for when we save for our retirement or when a corporate team sets up a long-term plan. Let us call that the 'relative future' - the future present, by which I mean the future of the present, the future to which the present is tending, the momentum of the present into a future that we can more or less see coming. [...] But there is another future, another thought of the future, a relation to another future, which is the future that is unforeseeable, that will take us by surprise, that will come like a thief in the night (I Thess. 5:2) and shatter the comfortable horizons of expectation that surround the present. Let us call this the 'absolute future'. When it comes to the relative future, the future present, we have 'reasonable expectations', 'cautious optimism', 'bulls and bears', but as regards the absolute future we must be like the lilies of the field who sow not, nor do they reap, but who are willing to go with what God provides, which also means that they are ready for anything. For the relative future we need a good mind, a decent computer, and horse sense, those three; for the absolute future, we need hope, faith, and love, these three (Caputo, 2001, pp. 7-8).

Although the process of sport training, with all its scientific support, is directed toward mastery over the future, that is into the 'future present' or 'relative future', everyday sport practices (especially competitions) show us that the 'absolute future' is at all times a concern. Nobody can know the outcome of the competition, and big surprises or 'miracles' are not something wholly unusual in sport (Fry, 2008). These facts clearly direct us to the religious or spiritual dimensions of sport, to the 'absolute future' where faith, hope and love are important. This is one reason why sport is today 'the last transformation of religion' or the place of religious or spiritual experiences for many people.

Further we can recognize that belief is not grounded on any special interest or constraint, but on our willful striving for the good. To put this differently: faith is a voluntary decision of the will in pursuit of the good. In this manner athletes voluntarily 
decide to do a workout and fulfil the demands of sport training, because he or she recognizes them to be good, a partial good on the way to some larger athletic goal. But, it must be emphasized, athletes do not have certain knowledge of the truth about the effects of training in advance. Their decision is made largely on goodwill, and priori expectation and experience of that goodwill in relation to the other.

So, uncertainty is always present. Uncertainty about the outcome maintains a degree of freedom in their faith; their belief is to some degree an act; a product of agency. And, precisely because of its voluntariness, the athlete is responsible and meritorious for the results of success or defeat in sport. At the same time, of course, uncertainty can be the source of doubt, which is a permanent companion of faith. On the one hand, uncertainty and doubt can be valued negatively, but on the other hand this can partly explain to us the attractive power of sport. Aquinas $(1955,3,40)$ claims that "the cognition of belief does not quiet the craving but rather kindles it". Sport is attractive precisely because it is uncertain, precarious: it is based on faith. ${ }^{3}$ It is uncertain for the athlete and trainer, as well as for fans. Everyone is longing for the knowledge that is still unknown in the future.

At last we must acknowledge that believing is included in any human learning. Aristotle (1994-2009, 165b) once said that "he who wishes to learn must believe". Anybody who wants to learn a new body movement or to gain special motor capabilities must believe those who have experiences and stand before him, who have already accomplished demands and can direct the novice in the right way. Without belief, any learning would become enormously demanding and very ineffective. What then of hope?

\section{Hope in sport}

For any religious or spiritual life the basic concept of status viatoris - the condition or state of "not yet" or of "being on the way" (Pieper, 2012, p. 91) - is foundational. Prayers and other spiritual exercises are the means, and not the end of spiritual life. Or, rather, there can be no clear separation of means and ends in a faithful life. It is not hard to recognize that the major part of the athlete's life is just that - being 'on the way'. Indeed, tragedies arise when that trajectory is no longer meaningful (Edgar, 2016), such as that experienced at the premature ending of a career by injury; or failure to make it to the next level; and so on. For most athlete daily workouts are not the aim, but simply the means to the end. The aim is to master some body 'techniques' or to achieve success in the competition.

But most of the time the athlete, as well as any human being, is in status viatoris, the state of 'not yet'. And hope is the virtue of 'not yet'. "It includes both a negative and a positive element: the absence of fulfilment and the orientation toward fulfilment" (Pieper, 2012, p. 93). Most of the time any athlete knows that he or she is not in a state of already having achieved the abilities he wants to have. So, hope is the reasonable response to this problematic: without it nobody would endure the process of training, because the aim is too far away. As we saw above, the unknown 'absolute future' is the

3 This is why the phenomenon of match fixing, or event manipulation, represents such a threat to sports integrity (Cleret, McNamee, \& Page, 2015). 
reality of sport. Nobody knows whether all the efforts of their training will bear fruit: the final results are uncertain at the time.

So hope must accompany any athlete, trainer or sports fan. Hope is directed into the future: it is not in fact here and now, but in hope it is. So in hope athletes, trainers and fans get a taste of the fruits before they ripen. Understood thus, hope can be the source of motivation and meaning for the daily efforts. It gives the power and energy to endure training until the day of the competition comes. Without hope, athletes would fall into despair.

Despair is one of two possible corruptions of hope. Beside despair the opposite kind of hopelessness is preasumptio or 'false hope'. "Preasumptio is a perverse anticipation of the fulfilment of hope. Despair is also an anticipation - a perverse anticipation of the nonfulfillment of hope" (Pieper, 2012, p. 113). Both of them transform the 'not yet' of hope into either the 'not' or the 'already' of fulfilment. While hope says: it will turn out well, despair says: it will turn out badly. Therefore despair is the characteristic state of those who have already - to some degree - given up. Any athlete or team who falls into despair before or during the competition, thereby enhances their likelihood to lose. With despair the athlete closes the door to success. This can be recognized as a distinction between big and small names in sport. The hopeful athlete does not stop until the end although the match seems already lost. There are numerous almost mythological stories from sport fields about a 'miraculous' recovery in a match that seemed completely lost, but when the result turned before the end of the game (Fry, 2008). Only those with strong hope can achieve victory in these cases. So it is clear why Aquinas (1920, II, II, 20, 3) claims that despair is not the most serious sin, but it is the most dangerous. And it is the most dangerous also for any serious athlete. One root of it is acedia or slothfulness. Pieper (2012, p. 119) defines it thus: "One who is trapped in acedia has neither the courage nor the will to be as great as he really is. He would prefer to be less great in order thus to avoid the obligation of greatness. Acedia is a perverted humility."

On the other hand, we can recognize preasumptio: presumption or 'false hope'. This disposition can be seen in some cases of doping-enhanced performance and other forms of cheating in sport. The doping or otherwise cheating athletes comes to believe that "he has actually attained the 'arduous' goal that, in reality, lies still in the future, the tension of the hope is relaxed in the middle of the 'way' and passes into the peaceful certainty of possession" (Pieper, 2012, p. 124). That happens in cases when the athlete or trainer does not wait or endure in the process of training until the time when the compensation of their athletic abilities will occur, and which will bring athlete to their peak performance. They want to make a shortcut to the result, sooner and/or with less hard work.

The other reason for presumption also common in sport practice is the athlete's need for security and certainty. Athletes paradoxically want what they cannot have: they want to be sure about their success in a venture where it cannot be known before the fact. They want to be secure in their results, but this can indirectly lead to the abuses of doping and cheating. A false self-esteem is common because there is no valid ground for it. Athletes and trainers need a special kind of humility manifested in stoic patience. Of course, here it is the coach who is usually the midwife of this virtue; reassuring the athlete, timing their entry to competitions or levels, staging skill acquisition with skillful timing, and so on. 
We saw that is not possible to fully dismiss the uncertainty of human existence, but we can fight against it with hope. This is especially true for athletes living in the uncertain world of sport. Hope is always connected with the future, whether it be my own future or the future of those I love.

\section{Love in sport}

What has love to do with sport? First of all we must recognize that love is a word with many meanings, from that on the 'yellow pages' or in teenage magazines on the one hand, to the deeper formulation of God as Love in Christian religion on the other. Therefore, it is necessary to expose some common characteristics of love. For now we will not go into different meaning of different words for love from Latin (e.g. amor, caritas, etc.) or Greek (e.g. agape, eros, philein, etc.). What do the different names for love have in common? One of the first things included in love is approval of someone or something. Pieper (2012, p. 164) puts it like this: "It's good that you exist!" Beside this love is usually something that comes upon us, not something that we decide for or do. Someone or something fascinates us and takes us over. At last, in the beginning of love, we are not so much active ourselves as stirred, changed, moved by something lovable. Plato in his Symposium (201a) maintained that the quality that makes a thing the object of possible love is beauty that attracts us as something perfect. Augustine makes a similar claim in his Confessiones (2009, 4, 13): "Do we love anything but the beautiful?" It is not for nothing that the slogan of one manufacturer before the FIFA 2006 soccer World Cup adopted the characterization 'the beautiful game'. The beauty of football makes the game liked and loved. Because the human being as such is not perfect, but is striving for perfection or fulfilment in different areas of his life, beauty attracts us. In this we will later recognize the love as eros. These few remarks are enough to start recognizing love in sport.

First of all we must recognize that to love something means to 'keep the beloved in being', to sustain its existence. Therefore if human beings have a power to do or not to participate in sport (literally to give - or not to give - existence to sport) the mere fact of existence of sport indicates that humans love sport. It is very simple: if people did not love sport, it would not exist because there can be any sport without human beings (Pisk, 2003, p. 159). From this ontological connection between human being and sport another characteristic of love in sport is derived: oneness. A common characteristic of love is "the reunion of those who have been alienated from one another. But alienation can exist only on the basis of a pre-existing original oneness" (Pieper, 2012, p. 160). At first sight this claim cannot be something special, but it can reveal some interesting insights of relation between being human and sport. If people love sport that can mean that in sport is something that corresponds to human being as such, to their human nature. People like sport because they recognize in sport something human, something that fits their nature. This claim could open the whole new theme of research: the question of human nature and sport. How they are interconnected, how sport can fulfil the natural potentials of human being, and how different understandings of human nature are reflected in different understandings of sport. Finally, sport can reveal to us something about our human nature (Pisk, 2014, p. 295). But these thoughts go beyond the scope of our present concerns. 
The next characteristic of love is that we are engrossed by it. "One of the ideas behind 'love," said Caputo, "is that it represents a giving without holding back, an 'unconditional' commitment, which marks love with a certain excess" (2001, p. 4). Similar experiences come from the world of sport when athletes and spectators are often totally taken over by sport. The etymology of fan - fanatic - is not idle here. This identification and commitment can go even to the level addiction with sport: they think that they cannot live without sport, being actively engaged in it or actively watching it. In either case, to love something means to give preference to it. The most of time and money is invested into the loved one. In this case danger arises because to love sport more than anything, means that everything is less important than sport. Sport can securely 'compete' for the love of human beings against other activities e.g. music, art, wine; but to love sport more than other human being means that 'in the name of sport' also some unethical decisions seem natural. In these cases our priorities are disordered. Humans can exist without sport, but sport cannot exist without human beings.

One of the most important characteristics of sport is the fact that in sport people can feel joy. And, if the source of joy is "our receiving or possessing something we love" (Pieper, 2012, p. 225), then the joy in sport reveals the love that partly comprises sport. But joy in sport is just one side of the coin. Probably everyone will acknowledge from his own experiences that love is also connected with pain and suffering. C. S. Lewis (1960, p. 169) once characterized what means to love somebody or something:

There is no safe investment. To love at all is to be vulnerable. Love anything, and your heart will certainly be wrung and possibly be broken. If you want to make sure of keeping it intact, you must give your heart to no one, not even to an animal.

And not even to sport, we can add. Love in sport is not connected only to the highest joy, but also to the deepest pain. Everyday experience shows that in sport there are many tears: tears of joy when athletes or teams succeed and tears of pain when things are not going as we wished. The athletes' tears reveal what really matters in sport and, as such, is a token of love in sport.

Leibnitz said that "to love means to rejoice in the happiness of another" (Pieper, 2012, p. 231). Rejoicing in the happiness of another can be seen daily on sport fields. Although only one athlete or team may win, this can bring happiness to the whole variety of people: not only their relatives and friends, but also fans, team mates and even other competitors. All of them can be fascinated with the performance of the winner, but identify with the merits of the loser(s) too. For example when the new record is made, or when a successful attempt of athlete is made. Examples of less tribal sports such a ski jumping offer arenas where there is widespread joy in great performances, no matter who performs them. Competitors are fascinated and congratulate the winner. This happiness is possible when there is a kind of love between competitors. Because love wishes only good to others, no matter how good he or she already is in reality, this means that love is faithful. This is an important characteristic of good spectatorship. ${ }^{4}$ A good fan will stay loyal to his team or athlete even though he or she

See also the contrast between Mumford (2013) and Culbertson (2015). 
is in a time of crisis and does not perform well. In difficulties one can get to know who are one's authentic friends, and in loyalty to athlete or team in case of defeat someone can prove a deep belonging, perhaps true love.

True love is without calculation - a fact that once again is proved in everyday sport reality. "Whoever seeks anything else in love except love will lose both love and the joy of love at the same time" (Pieper, 2012, p. 244). Whoever will cultivate sport because of any other reason than love for sport is apt to lose the very joy that sport can give. For example, when people practise sport predominantly or exclusively for other instrumental pragmatic reasons, like health, body weight control etc., they will likely lose their joy of and love for sport. It is possible to see daily that they no longer experience joy from sport. On the other hand whoever cultivates sport because of their love for it, he or she gets plenty of love, plenty of joy. Just take a look at children or other groups of people who voluntary engage in different sport activities. Listening to the loud laughter of the playground is evidence enough.

A special kind of love is friendship or the love of friends. Aristotle spoke in Nicomachean Ethics of philia, meaning a compassionate relation between friends. Once again, this is a kind of love we can readily find in sport. Friends usually do not speak of their friendships in the way that erotic lovers do about their love. Rather, "their gaze is fixed upon the things in which they take a common interest" (Pieper, 2012, p. 272). That is why sport has the power to weave friendships among, at first sight, incompatible people. Just call to mind examples of fans from different national, social, religious and other backgrounds. When they meet at the stadium or in the bar before or after the match, they meet as complete strangers to one another, but after a minute when they realize that they are supporting the same team, they become friends (and drink a beer together). Similarly, Pierre de Coubertin, the founder of modern Olympic Games, recognized the power of sport to work for peace in the world, using international meetings of athletes from different nations and building internationalism.

One of important characteristics of love is forgiveness. "Forgiveness is one of the fundamental acts of love," claims Pieper (2012, p. 189). Once again, it is hard to find any successful sport team where forgiveness does not have its place. Anywhere where many people live or work together, where there are strong relations of interdependence, as in team sports, the need for forgiveness is present. Without it, small resentments between players might grow into major disharmony. No matter how good its individual players, without forgiveness the team does not have good possibilities to succeed - or at least, they do not play to the maximum of their abilities. So a wise coach would take care about the relations inside the team, cultivating the environment of love between players and stimulating forgiveness as much as possible. Every form of love essentially seeks oneness and has union for its fruit (Pieper, 2012, p. 247), which is very important in any sport team. In team sports, an in relations within individual sports (such as with the coach and the athlete) reconciliation and harmony between actors are essential. The team must work as a unity, and love is the mean to achieve that.

One of the most well-known forms of love is eros. For ancient Greeks eros was the central word for love. Everything revolved around eros. Plato wrote extensively about it in his dialogue Symposium. However, because of some misunderstandings eros has in recent times got itself a 'bad name'. The undeserved reputation ignores the distinction 
between 'need-love' and 'gift-love', eros occupies the first one, the 'need-love' which was often characterized as selfish and not a 'true' love. However, as Pieper (2012, p. 222) has shown, this view is based on misunderstanding of human being as such. Nobody is perfect and everyone needs a lot of things. We can say that we are beings of need, of potentials which they try to fulfill. Therefore, eros corresponds to our human reality, which is 'on the way' to fulfilment of its potentials. Just give attention to our body needs and potentials: as bodily beings we need to preserve and develop the motor potentials of our body. We need bodily movement to function well. And if we are short of something (e.g. short of bodily movement) eros is the one which drives us into movement, into its own fulfilment. So, eros lies in the essence of sport as such because it is a 'natural' force directed into our own development. Eros is "the desire for full existence, for existential exaltation, for happiness and bliss” (Pieper, 2012, p. 234). As self-love, eros is also the root of all other love. It is the model and standard of love for others. Such 'self-love' can be recognized in recreational sport, which re-creates human being.

If eros is on the one side of a coin agape is on the other side. Agape (or in Latin caritas) is 'gift-love' - the original basic conception of love in Christianity. It is entirely unselfish love, the love that "does not seek to win life but dares to lose it" (Pieper, 2012, p. 211). It is love of sacrifice, which can be recognized in sport as well. One example of agape may be found in team sport where considerable sacrifice is required by individual players for the success of the team as a whole. Good players sacrifice for one another - is this not a sign of love? Moreover, in different 'fair play' acts, like when one competitor helps another who is in trouble, or lends him his sport equipment because his is broken, we can see agape. Sometimes athletes help their competitors, even though this may mean a loss for them. As Caputo said (2001, p. 4):

Love is not a bargain, but unconditional giving; it is not an investment, but a commitment come what may. Lovers are people who exceed their duty, who look around for ways to do more than is required of them.

Finally, we must acknowledge that every human being has a need to be loved, to get approval from other human being. According to Bauer (2008) this is the most important source of motivation for any human activity. In many cases sport can fulfil this need. Usually sport is a public activity, which means that an athlete is performing in front of an audience, who could be parents and friends, or fans and other people. No matter of the level of sport activities, sport gives us an offer to present our self, to gain respect or even become the idols of people. So the humans' need to be loved is partly fulfilled.

\section{CONCLUSION}

We have shown that sport is wholly impregnated with faith, hope and love - three classical theological virtues. From ancient times onwards, athletic events were connected with a human religious dimension, and nowadays sport is for many modern secular people the last transformation of confessional religion. In sports, non-believers too can experience some similar feelings which accompany confessional religious 
practices, starting with faith, hope and love. Caputo has said of religion what is also true of sport:

If safe is what you want, forget religion and find yourself a conservative investment counselor. The religious sense of life has to do with exposing oneself to the radical uncertainty and the open-endedness of life, with what we are calling the absolute future, which is meaning-giving, salt-giving, risk-taking [...] The absolute future is a risky business, which is why faith, hope, and love have to kick in (Caputo, 2001, p. 14).

These ideas point not merely to similarities between religion and sports. As we have seen, they rather point out the sharedness of form between the two. They also point to the value of considering more seriously the place of the theological virtues in sport.

\section{REFERENCES}

Aquinas, T. (1920). Summa Theologica. Retrieved 25.05.2016 from: http://www.newadvent .org/summa.

Aquinas, T. (1955). Contra gentiles. New York: Hanover House. Retrieved 25.05.2016 from: http://dhspriory.org/thomas/ContraGentiles.htm.

Aristotle. (1994-2009). On Sophistical Refutations. Retrieved 25.05.2016 from: http://classics .mit.edu/Aristotle/sophist_refut.html.

Aristotle. (1994-2009). Nicomachean Ethics. Retrieved 25.05.2016 from: http://classics.mit .edu/Aristotle/nicomachaen.html.

Augustine (1955). Enchiridion: On Faith, Hope, and Love. Dallas: Southern Methodist University.

Augustine (2009). The Confessions. Retrieved 25.05.2016 from: http://www.augustinus.it /links/inglese/opere.htm.

Bauer, J. (2008). Princip človeškosti [The Principle of Humanity - Why we co-operate by nature]. Ljubljana: Študentska založba.

Caputo, J. D. (2001). On Religion. London and New York: Routledge.

Cleret, L., McNamee, M. J., \& Page, S. (2015). 'Sports Integrity' Needs Sports Ethics (and sports philosophers and sports ethicists too). Sport, Ethics and Philosophy, 9(1), 1-5.

Compendium of the Catechism of the Catholic Church. (2005). Vatican: Libreria Editrice Vaticana. Retrieved 25.05.2016 from: http://www.vatican.va/archive/compendium_ccc/documents/archive_2005_compendium-ccc_en.html.

Culbertson, L. (2015). Perception, Aspects and Explanation: Some Remarks on Moderate Partisanship. Sport, Ethics and Philosophy, 9, 182-204.

Fry, J. (2008). On Fumbling the Ball. In: M. W. Austin (ed.), Football and philosophy going deep (pp. 18-30). Kentucky: The University Press of Kentucky.

Jirásek, I. (2015). Religion, Spirituality, and Sport: From Religio Athletae Toward Spiritus Athletae. Quest, 67, 290-299.

Kant, I. (1896). Critique of Pure Reason. New York: 1873 Press.

Lewis, C. S. (1960). The Four Loves. Harccurb: Braes.

Luckmann, T. (1967). The Invisible Religion. New York: The Macmillan Company.

Marx, K. (2009). Critique of Hegel's Philosophy of Right. Retrieved 25.05.2016 from: https:// www.marxists.org/archive/marx/works/1843/critique-hpr/intro.htm.

Mumford, S. (2013). Watching Sport: Aesthetics, Ethics and Emotion. London: Routledge.

Novak, M. (1988). The Joy of Sports. Lanham: Hamilton Press.

Parry, J. (2007). The 'Religio Athletae', Olympism and Peace. In: J. Parry, et al. Spirituality and Sport (pp. 201-214). London: Routledge. Reprinted in Georgiadis, K. and Syrigos, A. 
Olympic Truce - sport as a platform for peace (pp. 37-49). Athens: International Olympic Truce Centre, 2009.

Pieper, J. (2012). Faith, hope, love. San Francisco: Ignatius Press.

Pisk, J. (2003). Sport and Being as Being. In: M. Hosta (Ed.), Philosophy of Sport and Other Essays. Ljubljana: Fakulteta za šport.

Pisk, J. (2010). (Ne)vidna religija športa [(In)visible religion of sport]. Šport, 1-2, 65-68.

Pisk, J. (2012). Search for Immortaliy in Ancient and Modern Sport. Physical Culture and Sport. Studies and Research, LIV, 5-12.

Pisk, J. (2014). Misliti šport: filozofska analiza športa [Thinking sport: philosophical analysis of sport]. Ph.D. diss. University of Ljubljana.

Plato. (1994-2009). Symposium. Retrieved 25.05.2016 from: http://classics.mit.edu/Plato /symposium.html.

Ratta, A. (2014). Making Spiritual Progress: Building Your Life with Faith, Hope, and Love. Downers Grove: IVP Books.

Sansone, D. (1993). Greek Athletics and the Genesis of Sport. Berkeley: University of California Press.

Vodeb, R. (2001). Šport skozi psihoanalizo [Psychoanalysis of sport]. Trbovlje: Fit. 